\title{
Documenting the copyright sphere: can festivals solve the problem of copyright clearance for documentaries?
}

\author{
Oğulcan Ekiz* \\ $\mathrm{PhD}$ Candidate, Queen Mary University of London
}

The starting point of this article is a short documentary film that I and five colleagues produced in the course of the Business of Film module at Queen Mary University of London's Intellectual Property Law LLM Programme. During the process of production, we faced some borderline issues regarding our unauthorized uses of others' copyright works. When we put ourselves into the copyright's author's shoes, three problems arose regarding our use of possible limitations and exceptions: the lack of guidance; the fear of liability; and the unharmonized status of limitations and exceptions at an international level. This article examines these problems from a copyright policy perspective and invites documentary festivals to undertake a mission of guiding new documentary directors through the complex, unharmonized world of copyright limitations and exceptions.

Keywords: limitations and exceptions, freedom of panorama, copyright clearance, documentary, documentary film festivals

\section{INTRODUCTION}

If you live in an urban area, as 55 per cent of the world's population does nowadays, ${ }^{1}$ you have likely encountered copyright-protected materials today. They may be in the form of a ringtone you heard on public transportation, images on a passer-by's shirts or in advertisements on billboards that are quite hard to miss. Copyrighted works constitute a large portion of the public space, especially in urban life. This is quite normal, considering that what copyright regulates is strongly connected to the distribution of a work and what you see are the copies of the work distributed. But, what if you were to publish a documentary about this urban space? Would you be required to pinpoint each copyright-protected material and obtain the necessary authorization to

* This research was conducted while the author was a Masters student at Queen Mary University of London, Intellectual Property Law LLM Programme. The author would like to thank Professor Johanna Gibson for her extensive and valuable comments, his colleagues Francesco Nisi, Louise Perrotte, Lucie Brismontier-Thouny, Rabia Diallo and Vivianna-Paraskevi Paschou, with whom he produced Her Story in the course of the Business of Film Module, and his family for their endless support in the course of his education.

1. The United Nations, ' $68 \%$ of the World Population Projected to Live in Urban Areas by 2050, says UN', available at <https://www.un.org/development/desa/en/news/population/2018revision-of-world-urbanization-prospects.html> last accessed 22 July 2019. 
include them? While some documentarians may choose to follow this path, for others, this may be too big of an expense. ${ }^{2}$

Copyright clearance is one of the most expensive and tedious parts of documentary filmmaking. Such a costly and time-consuming process that has little to do with the creative output of the process of filmmaking may be discouraging for filmmakers, especially those who are at the beginning of their careers. Its significance has been well documented within the copyright discourse, and copyright's limitations and exceptions are suggested as a way to avoid such expenses. ${ }^{3}$ Indeed, the limitations and exceptions could provide a shield for many uses. Nonetheless, this article will argue that the current limitations and exceptions scheme fails to help documentary makers on three grounds, which will be explained in detail below. First, the implementations of limitations and exceptions are not always crystal clear and the documentary community lacks the know-how to utilize them. Second, there is a risk of copyright infringement associated with utilizing limitations and exceptions, which, as exemplified below, leads people to avoid utilizing limitations and exceptions. Third, limitations and exceptions remain unharmonized at the international level. Therefore, utilizing limitations and exceptions may be hard for documentaries that aim to reach an international audience.

This article examines documentary festivals as offering a solution to the problem of copyright clearance for documentaries. It is argued that festivals could provide clarity for documentary filmmakers, which is necessary for utilizing limitations and exceptions. Hence, they may reduce the risk of copyright infringement associated with utilizing them.

The article is first going to examine the current scheme of copyright clearance for documentaries. The following section will focus on limitations and exceptions. Our experience with Her Story, the short documentary we made for the Business of Film module, and the way we tried to facilitate the so-called freedom of panorama exception in three different jurisdictions will then be exemplified to reflect the difficulties of utilizing limitations and exceptions in different countries. In section 4 festivals will be examined as suitable solutions to the problem of copyright clearance for documentaries.

\section{SOLELY RESPONSIBLE: COPYRIGHT CLEARANCE AND FEAR OF LIABILITY}

Bill Nichols argues that there are three central features of the documentary medium: evidence, narrative and ethics. ${ }^{4}$ While the latter two are subjective in the sense that the way they shape a documentary depends on the personal values and characteristics of the documentary maker, the evidence is the external factor that ensures

2. Not to mention that some rightholders may be reluctant to grant authorization even if a documentary maker is ready to pay for the licence fee.

3. See, Patricia Aufderheide and Peter Jaszi, 'Untold Stories: Creative Consequences of the Rights Clearance Culture for Documentary Filmmakers', Center for Social Media, 2004, at 7-9. In Canada, copyright clearance costs up to $27 \%$ of a film's budget. See, Documentary Organization of Canada (DOC), Copyright and Fair Dealing: Guidelines for Documentary Filmmakers (DOC 2010) at 5.

4. Bill Nichols, 'The Question of Evidence, the Power of Rhetoric and Documentary Film', in Brian Winston (ed), The Documentary Film Book (BFI, London 2013) at 33. 
the credibility of the film. ${ }^{5}$ Therefore, the evidence is the feature that supports the narration and the point of view of the documentary, ${ }^{6}$ by gaining the trust of the spectator. ${ }^{7}$ But what if the evidence, the external element that the documentary maker's narration is built upon for the sake of her argument, is a copyrighted work? Documentaries represent our shared world, ${ }^{8}$ and copyrighted works constitute a great part of this world, especially in urban life. ${ }^{9}$ While for some documentaries the copyrighted work is the subject, ${ }^{10}$ for many others, it should be there to provide a faithful representation of the actuality. But once the copyrighted work is there, the documentary maker is the one who is expected to carry the burden of copyright clearance. ${ }^{11}$

The industry has a strict approach regarding unauthorized uses of copyright works. Generally, broadcasters require documentaries to have an Errors and Omissions insurance $(E \& O)$ secured against an infringement claim. ${ }^{12}$ And the insurance company is more willing to offer such insurance if the film contains no unauthorized uses. ${ }^{13}$ As a result, the documentary makers either seek authorization for their uses, regardless of a possible limitation or exception that would cover the specific use, or make changes to the footage and cut out the copyright material. One example, which had a strong fair use claim under US law, was an incidental use of four-and-a-half seconds of footage from The Simpsons in Jon Else's Sign Faster: The Stagehand's Ring Cycle. During the shootings of the scene, which features the stagehands of the San Francisco Opera playing checkers, the camera caught an episode of The Simpsons for 4.5 seconds. ${ }^{14}$ The show was playing on a TV that was in the background of the scene. ${ }^{15}$ The licence fee asked for the use of 4.5 seconds was $\$ 10,000$, which was found too high and the scene was replaced with piece of previously shot footage. ${ }^{16} \mathrm{Mr}$ Else stated that 'I'm willing to sacrifice a wonderful droll cultural moment - the stagehands watching 'The Simpsons' - to avoid being taken to court. ... Who loses is the audience in the end. ${ }^{17}$

\section{Ibid at 33-4.}

6. See Susan Sontag, Regarding the Pain of Others (Penguin, London 2004) at 23. (In her landmark essay about photojournalism, a medium that has close links with documentary making in the sense that it has the same three central features of evidence, narrative and ethics, Susan Sontag states that the medium is dual in its nature, and it unites two contradictory features; objectivity and point-of-view: 'they always had, necessarily, a point of view'.)

7. Dirk Eitzen, 'When is a Documentary? Documentary as a Mode of Reception' (1995) 35(1) Cinema Journal 81 (stating that: 'All documentaries - whether they are deemed, in the end, to be reliable or not - revolve around questions of trust').

8. Bill Nichols, Introduction to Documentary (Indiana University Press, Bloomington, IN 2010) at 20.

9. For a visual representation of how much of the urban place is occupied by copyright works, see Keith Aoki, James Boyle and Jennifer Jenkins, Bound by Law? Tales from the Public Domain. New Expanded Edition (Duke University Press, Durham, NC 2008) at 6-9.

10. See eg Benjamin Franklin and Kembrew McLeod, Copyright Criminals (2009); Malik Bendjelloul, Searching for Sugar Man (2012); John Maloof and Charlie Siskel, Finding Vivian Maier (2013).

11. Aufderheide and Jaszi (n 3) at 9-10.

12. Winnie Wong, 'Errors \& Omissions \& Rights, Oh My! A Guide to Protecting Your Film', IDA Documentary Magazine, 6 April 2012, available at <https://www.documentary.org/magazine/ errors-omissions-rights-oh-my-guide-protecting-your-film> last accessed 23 July 2019.

13. Ibid.

14. Neil Weinstock Netanel, Copyright's Paradox (Oxford University Press, Oxford 2008) at 16.

15. Ibid.

16. Ibid at $16-17$.

17. Aufderheide and Jaszi (n 3) at 17. 
While festivals are argued to be more benevolent than television distribution, ${ }^{18}$ the following language is common in the process of submissions:

Applicants are solely responsible for obtaining all necessary rights and permissions for thirdparty materials included in their films, including but not limited to music, trademarks, logos, copyrights, and other intellectual property rights. ${ }^{19}$

Finding themselves as solely responsible against the risk of notoriously costly lawsuits, documentary makers may feel forced to either seek authorization or cut out the scene, even though their use might be covered by an exception. The producers of the 2005 documentary, Mad Hot Ballroom had to negotiate with EMI music, the copyright owner of the record Gonna Fly Now that the camera caught when the interviewee's phone rang since the song was the ringtone of the interviewee. ${ }^{20}$ Even though Amy Sewell, the writer and co-producer of Mad Hot Ballroom, thought the use was lawful under the fair use doctrine of the US, the legal advice was as follows: 'Honestly, for your first film, you don't have enough money to fight the music industry'. ${ }^{21}$ The documentary had a stated budget of $\$ 500000,{ }^{22}$ and a strong fair use argument. But negotiating for a licence was a safer choice in the face of an infringement claim.

With more and more people seeking licences for borderline uses to avoid a possible copyright infringement claim; it becomes harder for subsequent users to rely on limitations and exceptions, as seeking authorization becomes the norm in the day-to-day operations of the industry. ${ }^{23}$ The result is that utilizing limitations and exceptions is reduced to a marginalized position within the industry, and copyright clearance becomes a significant part of the budget for documentaries. Considering that the licence fees are subject to negotiation, the cost of copyright clearance may easily overtake the predicted budget. Tarnation, a 2004 homemade documentary by Jonathan Caouette about his life and his relationship with his mother, reportedly cost $\$ 218$ to produce. ${ }^{24}$ The cost, however, rose to the amount of $\$ 400,000$ when Caouette decided to distribute it, more than half of it to be spent on copyright clearance. ${ }^{25}$ Our project is more modest in its budget, which is $£ 3500$. We projected spending 15 per cent of the budget in obtaining the relevant licences for the UK territory for the music we use. But, if Her Story were to be selected by one of the overseas festivals we submitted it to, an additional cost for licensing each use in an additional territory will arise. And some of the uses that we do not seek to license due to limitations and exceptions under the Copyright Designs and Patents Act (CDPA) 1988 are not covered by the

18. Aufderheide and Jaszi (n 3) at 10.

19. Austin Film Festival, '2018 Austin Film Festival Film Competition Rules', available at $<$ https://austinfilmfestival.com/submit/film/rules/> last accessed 23 July 2019. Similar terms are stated in other film/documentary festivals, such as the New Orleans Film Festival, DOC NYC, and the Camden International Film Festival.

20. Nancy Ramsey, 'The Hidden Cost of Documentaries', The New York Times, 16 October 2005, available at <http://www.nytimes.com/2005/10/16/movies/the-hidden-cost-of-documen taries.html> last accessed 23 July 2019.

21. Ibid.

22. Ibid ( $34 \%$ of the budget was reported to have been spent on copyright clearance for music).

23. See Matthew Africa, 'The Misuse of Licensing Evidence in Fair Use Analysis: New Technologies, New Markets, and the Courts' (2000) 88(4) Cal. L.J. 1145, at 1172-3.

24. See Gareth McLean, 'My Life, The Horror Movie', The Guardian, 16 April 2005), available at $<$ https://www.theguardian.com/film/2005/apr/16/features.weekend > last accessed 23 July 2019.

25. Aufderheide and Jaszi (n 3) at 7. 
other countries' copyright regulations. The issue of limitations and exceptions will be specifically examined in the next section; however, some additional costs may arise due to the unharmonized limitations and exceptions regulations.

\section{LIMITATIONS AND EXCEPTIONS: UNRELIABLE, UNHARMONIZED}

Limitations and exceptions have been suggested as a way to lighten the burden for documentary makers caused by the excessive copyright clearance scheme of the industry. ${ }^{26}$ However, such studies tend to focus on one jurisdiction and its limitations and exceptions regulations in particular. Even though the necessity of internationally coherent copyright regulations has been stated since the nineteenth century, ${ }^{27}$ there are still significant differences among national copyright regulations. The differences are particularly noteworthy when it comes to limitations and exceptions. ${ }^{28}$ It is hard to argue that every use that is covered by the fair use exception of the US would also be covered by one of the fair dealing exceptions in the UK, or one of the closed list exceptions of the countries of continental Europe. Therefore, even though the cited studies are helpful for documentarians, their effectiveness may be limited to one territory.

A number of commentators have argued in favour of an international instrument to achieve an internationally harmonized limitations and exceptions scheme. ${ }^{29}$ However, it would not be an easy task to achieve mutual compromises on such a large scale among countries with significantly diversified regulations. Limitations and exceptions are subject to the so-called three-step test, which was first introduced to Article 9(2) of the Berne Convention for the Protection of Literary and Artistic Works (Berne Convention) at the 1967 Stockholm Conference. ${ }^{30}$ The initial regulation was directed to the right of reproduction that is regulated under Article 9(1) of the Berne Convention. ${ }^{31}$ The three-step test, then, reappeared in both international instruments like Article 13 of the Agreement on Trade-Related Aspects of Intellectual Property Rights (TRIPS) and Article 10 of the WIPO Copyright Treaty (WCT), as well as

26. See Association of Independent Video and Filmmakers and others, Documentary Filmmakers' Statement of Best Practices in Fair Use (AUSOC 2005); DOC (n 3); Michael C Donaldson, 'Refuge from the Storm: A Fair Use Safe Harbor for Non-Fiction Works' (2012) 59 J. Copyright Soc'y USA 477; Patricia Aufderheide and Aram Sinnreich, 'Documentarians, Fair Use, and Free Expression: Changes in Copyright Attitudes and Actions with Access to Best Practices' (2016) 19(2) Information, Community \& Society 178.

27. See Brad Sherman and Lionel Bently, The Making of Modern Intellectual Property Law: The British Experience (Cambridge University Press, Cambridge 1999) at 111-115; Sam Ricketson and Jane C Ginsburg, International Copyright and Neighbouring Rights: The Berne Convention and Beyond (2nd edn, Oxford University Press, Oxford 2006) at 3-41.

28. See P Bernt Hugenholtz and Martin RF Senftleben, Fair Use in Europe: In Search of Flexibilities (IViR, 2011) (comparing the different interpretations of the quotation exception among European countries); Guisseppina D'Agostino, 'Healing Fair Dealing? A Comparative Analysis of Canada's Fair Dealing to U.K. Fair Dealing and U.S. Fair Use' (2008) 53 McGill L.J. 309.

29. See P Bernt Hugenholtz and Ruth L Okediji, Conceiving an International Instrument on Limitations and Exceptions to Copyright: Final Report (IViR, UMLS March 6, 2008); Daniel J Gervais, 'Making Copyright Whole: A Principled Approach to Copyright Exceptions and Limitations' (2008) 5 U. Ottawa L. \& Tech. J. 1.

30. Hugenholtz and Okediji (n 29), at 16.

31. See Berne Convention, Article 9(1). 
regional regulations such as the Information Society Directive, ${ }^{32}$ hence expanding the three-step test requirements to other exclusive rights as well. The three-step test states that limitations and exceptions should be confined to (1) 'certain special cases', which (2) 'do not conflict with a normal exploitation of the work', and (3) 'do not unreasonably prejudice the legitimate interests of the right holder'. ${ }^{33}$ The World Trade Organization (WTO) Panel is the only international adjudicative body that has interpreted the three-step test, where they stated that $\$ 110(5)$ of the US Copyright Act was in violation of the three-step test of the TRIPS Agreement. ${ }^{34}$ It is outside the scope of this article to provide a detailed review of the WTO decision; ${ }^{35}$ however, a number of commentators have argued that the decision fails to provide the predictability that is needed to achieve an internationally harmonized limitations and exceptions regime. ${ }^{36}$ In the current situation, the industry stakeholders, who conceptualize copyright first and foremost as private property, ${ }^{37}$ are inclined to push for a narrow interpretation of the test that creates an obstacle for policymakers. ${ }^{38}$ Therefore, the issue of harmonization of the limitations and exceptions remains to be resolved.

In this part of the article, I provide an examination of our unauthorized uses of two sculptures in Her Story that are on public display. I consider whether our uses are covered by the so-called panorama exception regulations of three EU jurisdictions, namely the UK, France and Germany. These three countries were selected to be the subject of my examination for the following two reasons: firstly, we wished to screen our documentary in these three markets; secondly, and more importantly, all three countries' regulations are subject to the Information Society Directive, which provides a nonmandatory panorama exception for the Member States under Article 5(3)(h). Therefore, their national provisions are subject to 'a coherent application' among the other EU Member States. ${ }^{39}$ Moreover, the Court of Justice of the European Union's (CJEU) conceptual interpretation of parody as 'an autonomous concept of EU law' in the judgment of Deckmyn v Vandersteen (Deckmyn $)^{40}$ further emphasized the importance of a harmonized limitations and exceptions system among EU Member States. ${ }^{41}$ However, as the following examination will further illustrate, despite these efforts to achieve a more autonomous limitations and exceptions system, relying on

32. See Article 5(5).

33. TRIPS, Article 13.

34. Fairness in Music Licensing, Panel Report, June 15, 2000, WT/DS/160/R, 7.1.

35. For a detailed examination, see Jane C Ginsburg, 'Toward Supranational Copyright Law? The WTO Panel Decision and the "Three-Step Test" for Copyright Exceptions' (2001) 187 R.I. D.A. 2.

36. Ibid at 16 (stating that 'the Panel decision may have clarified the terms of reference, but it may not have made future outcomes any more predictable').

37. Keith Aoki, 'Adrift in the Intertext: Authorship and Audience Recording Rights Comment on Robert H. Rotstein, Beyond Metaphor: Copyright Infringement and the Fiction of the Work' (1993) 68 Chi.-Kent L. Rev. 805 at 809-10.

38. See, in general, Jonathan Griffiths, "Rhetoric \& the "Three-Step Test": Copyright Reform in the United Kingdom' (2010) 32(7) E.I.P.R. 309 (examining the arguments of organizations that lobbied on behalf of rightholders during the copyright reform discussions in the UK).

39. See Directive 2001/29, Recital (32).

40. Case C-201/13, Johan Deckmyn and Another $v$ Helena Vandersteen and Others, Judgment of the Court of Justice (Grand Chamber) of 3 September 2014, EU:C:2014:2132 at [15].

41. See Christopher Geiger et al., 'Limitations and Exceptions as Key Elements of the Legal Framework for Copyright in the European Union - Opinion of the European Copyright Society on the Judgment of the CJEU in Case C-201/13 Deckmyn' (2015) 46(1) Int. Rev. of I.P. and Comp. L. 93, at 95-6. 
limitations and exceptions in different jurisdictions is still a burdensome task, even within the EU.

\subsection{The permanently temporary sculptures of the Fourth Plinth}

One of the central parts of Her Story's narration is the \#March4Women 2018 march, which took place on 4 March 2018. We followed the march from outside the Houses of Parliament to Trafalgar Square and continued to document the gathering at Trafalgar Square. The documentary features several close-ups, wide-angle shots and portraits of interviewees, both during the march from the Houses of Parliament to Trafalgar Square and at the Square itself. During the shooting, we recorded many sculptures that were on public display. The Square hosts artworks from different periods and some art historians argue that its power to reflect a historical narration of the UK comes from those artworks' ability to develop a collective memory among people. ${ }^{42}$ The Square, with its significance in its representational power of the British identity, is more than a mere place where the event happened. It is the place for reshaping the collective memory on gender equality. Therefore, including wide-angle shots to show the relationship between the march and the Square was necessary for our documentary, both as a part of the narration and as a reliable representation of the actuality. And such a frame has no choice but to include the artworks displayed in the Square, for two intertwined reasons: first, it is almost impossible to frame the Square without the artworks; second, and more importantly, the Square is what it is because of the artworks. Therefore, for our evidence to be externalized, in other words for us to create a reliable representation of the actuality, the artworks should be featured in the documentary. However, not all of the artworks the Square hosts are in the public domain. Since 1999, the Fourth Plinth in the Square has hosted commissioned artworks, ${ }^{43}$ and its guest sculpture was David Shrigley's Really Good during the \#March4Women $2018 .{ }^{44}$ Really Good is a sculpture that features a human hand, shaped in the form of a thumbs-up, with an abnormally long thumb. Due to the shape and the length of the thumb, the sculpture was defined as a phallic object by some commentators. ${ }^{45}$ Considering the relation between the Square and the march, and the relation between Really Good and the Square, Really Good's representation in the documentary was seen as essential for Her Story. Not to mention that its size makes it nearly impossible to keep it out of the frame. Thus, keeping it outside of the frame would mean intentionally excluding a significant part of the march from the documentary.

42. See Deborah Cherry, 'Statues in the Square: Hauntings at the Heart of Empire' (2006) 29(4) Art History 660; Shanti Sumartojo, 'Britishness in Trafalgar Square: Urban Place and the Construction of National Identity' (2009) 9(3) Studies in Ethnicity and Nationalism 410.

43. See Shanti Sumartojo, 'The Fourth Plinth: Creating and Contesting National Identity in Trafalgar Square, 2005-2010' (2012) 20(1) Cultural Geographies 67.

44. See Jess Denham, 'Fourth Plinth: David Shrigley's Giant Thumbs Up "Really Good" Unveiled in London's Trafalgar Square', Independent, 29 September 2016, available at $<$ https://www.independent.co.uk/arts-entertainment/art/news/fourth-plinth-david-shrigley-trafalgarsquare-sadiq-khan-really-good-thumbs-up-london-brexit-a7337026.html > last accessed 23 July 2019.

45. See eg Jonathan Jones, 'Thumbs Up to David Shrigley's Fabulously Feel-Bad Fourth Plinth', The Guardian, 29 September 2016, available at <https://www.theguardian.com/artand design/2016/sep/29/david-shrigley-really-good-fourth-plinth-trafalgar-square $>$ last accessed 23 July 2019. 
Another sculpture that is featured in Her Story is the Monument to the Women of World War II (Monument), made by the British sculptor John William Mills. ${ }^{46}$ The sculpture is located in the centre of Whitehall between the Cabinet Office and the Ministry of Defence, on the route taken by the \#March4Women. Many people that attended the march engaged with the sculpture. Some took selfies with it, and others just saluted it. Considering the conceptual message of the Monument, we decided to record and feature some of the engagements with it. However, the Monument is under copyright protection, just like Really Good. Thus, to be able to legally feature the two sculptures, we either had to license our uses or rely on an exception.

Section 62 of CDPA 1988 provides an exception for the representation of certain artistic works that are on public display. ${ }^{47}$ According to the provision, users can make a film of a sculpture without a licence, if the sculpture is 'permanently situated in a public place or in premises open to the public' ${ }^{48}$ There is no question that both Trafalgar Square and Whitehall are public places. ${ }^{49}$ And, even though the concept of sculpture has been particularly problematic in copyright discourse, covering the interpretation of the term sculpture is outside the scope of this article. ${ }^{50}$ A possible problem, however, may arise from the requirement of permanence for our use of Really Good ${ }^{51}$ because sculptures are displayed on the Fourth Plinth for a certain period. While there are no plans to relocate the Monument, Really Good was due to relinquish its place to Michael Rakowitz's The Invisible Enemy Should Not Exist in the same month as we recorded the march. ${ }^{52}$ But does that mean that Really Good was displayed to the public temporarily? Or is making a different interpretation of the term permanently possible in the context of the legal framework in which it is used?

The origins of the provisions of Section 62 go back to the 1911 Copyright Act. ${ }^{53}$ According to the relevant provisions of the 1911 Act, the following uses would not constitute copyright infringement: 'The making or publishing of paintings, drawings, engravings, or photographs of a work of sculpture or artistic craftsmanship, if permanently situate in a public place or building' ${ }^{54}$

46. See Imperial War Museum, 'Memorial: Women of World War Two', available at <https:// www.iwm.org.uk/memorials/item/memorial/51288> last accessed 23 July 2019.

47. CDPA s 62.

48. CDPA s 62(1)(b).

49. See Cherry (n 42); Sumartojo (n 43); Lionel Bently and Brad Sherman, Intellectual Property Law (4th edn, Oxford University Press, Oxford 2014) at 265 (suggesting Trafalgar Square as an example of public space).

50. For a comprehensive analysis of the concept of sculpture in art and law, see Deming Liu, 'Of Sculpture' (2014) 36(4) E.I.P.R. 229.

51. See Deming Liu, 'English Copyright Law Makes the Poor "Snowman" Sculpture Poorer' (2013) 35(11) European I.P. L. 674, at 676-7 (stating that more than one interpretation of the word permanently is possible).

52. See Sadiq Khan, Mayor of London, MD2179 Fourth Plinth Programme 2017-2021 (26 October 2017), available at <https://www.london.gov.uk/sites/default/files/md2179_fourth_ plinth_cib_final_version_signed_pdf.pdf> last accessed 23 July 2019 (approving the next two artworks to be displayed on the Fourth Plinth: Michael Rakowitz's The Invisible Enemy Should Not Exist to be erected in March 2018, and Heather Phillipson's THE END to be erected in March 2020).

53. For a comparison of the provision throughout the 1911, 1956 and 1988 Acts, see Robert Burrell and Allison Coleman, Copyright Exceptions: The Digital Impact (Cambridge University Press, Cambridge 2005) at 233-4.

54. Copyright Act 1911 s 2(1)(iii). 
The legislative history suggests that the aim of securing certain uses of certain works that were permanently displayed in a public space was the conceptualization of those works as belongings of the nation:

There may be, for instance, a very beautiful design in a public place-in Trafalgar Square, for instance-which belongs to the nation, and you do not want it to be an infringement of copyright for anybody to make a sketch of that. ${ }^{55}$

For sure the public sculptures do not belong to the nation in the sense of owning a property. Rather, what was emphasized is the continuous relationship between the sculptures and the people due to the sculptures' positioning in the public space. Applying Hannah Arendt's public/private realm distinction, ${ }^{56}$ they are different to a sculpture located in a private place, because everyone can interact with them without any authorization. ${ }^{57}$ The result of their constant presence in people's sight is an ongoing interaction with people. While on one hand the meaning of the sculpture is constantly redefined as a result of the ongoing interaction, ${ }^{58}$ on the other hand, with the continuous reconstitution of its meaning, the sculpture's impact on the collective memory gains a dynamic status. ${ }^{59}$ The legislative history recognizes this dynamic status of public sculptures and safeguards a stable interaction between people and public sculptures by blocking an unreasonable limitation that would have arisen by the given copyright protection.

The sculptures of the Fourth Plinth may be on display temporarily, but each of them has been displayed continuously. ${ }^{60}$ Therefore, it is expected that those sculptures will be a part of the public space for pre-established periods. ${ }^{61}$ Furthermore, even though the works are to be temporarily displayed, the act of displaying the selected works is ongoing, ${ }^{62}$ thus making the Fourth Plinth a permanent host of sculptures in the public

55. Viscount Haldane, Imperial Copyright, Hansard, HL, Vol. 10, cols 113-66 (emphasis added).

56. Hannah Arendt, The Human Condition (2nd edn, The University of Chicago Press, Chicago, IL 1958) at 22-79.

57. Ibid at 50 .

58. My argument follows Roland Barthes' post-modernist suggestion of the reader as the meaningmaker. See Roland Barthes, Image, Music, Text, Stephen Heath trans (Fontana Press, London 1977) at 142-9. For a counter-argument regarding the application of Barthes' manifesto to the realm of copyright, see Aoki (n 37) at 809-10.

59. Umut Özkırıml1, Contemporary Debates on Nationalism: A Critical Engagement (Palgrave Macmillan, Basingstoke 2005) 170 (arguing that people's relation with culture brings a dynamism to the process of shaping a national identity).

60. Antony Gormley's 2009 commission, One \& Other might be separated from other commissions in the context of continuum. The work was a collaborative performance of 2400 people, each of them standing on the plinth for one hour during 100 consecutive days, 24 hours a day. See Antony Gormley, 'One \& Other, Fourth Plinth Commission, Trafalgar Square, London, England, 2009', available at <http://www.antonygormley.com/show/item-view/id/2277> last accessed 23 July 2019.

61. See eg Khan (n 52).

62. See City of Westminster, Planning Applications Sub-Committee Report on Trafalgar Square, London, WC2 (16 February 2012) at 232, available at <http://committees.westminster.gov.uk/ Data/Planning\%20Applications\%20Committee/20120216/Agenda/ITEM\%2007-Trafalgar\% 20Square,\%20WC2.PDF> last accessed 23 July 2019 (following the positive public interest in the Fourth Plinth shown for the first three works, the committee suggested that the plinth 'continue to be used for an ongoing series of temporary works of art commissioned from leading national and international artists'). 
space. In this context, the sculptures of the Fourth Plinth are a part of London's daily life, and they are in continuous interaction with people. Therefore, including the sculptures displayed on the Fourth Plinth within the scope of section 62 would be following Parliament's rationale for the provision.

However, even if our uses of Really Good and the Monument fall within the scope of section 62 of CDPA 1988, the exception only covers our uses within the UK territory. If we were to be selected for one of the festivals outside the UK, the legality of our uses without authorization would depend on the relevant country's copyright regulations.

\subsection{Different scenarios for different countries}

Article 5(3)(h) of the Information Society Directive provides a similar exception for the Member States. According to the so-called panorama exception provision, Member States may provide an exception for the rights of reproduction and communication to the public for the 'use of works, such as works of architecture or sculpture, made to be located permanently in public places' ${ }^{63}$ However, since the exception is not mandatory, not all countries include such an exception to their copyright acts. ${ }^{64}$ And the implementation varies among countries that provide the panorama exception. ${ }^{65}$ The regulations of Germany and France, two of the countries in which we hope to screen our documentary via festivals, are demonstrative of the lack of harmonization.

With the priority given to authors' interests in their self-expression, ${ }^{66}$ France was against implementing the panorama exception for a long time. ${ }^{67}$ Since 7 October 2016, however, France has had a limited exception for reproducing and representing works that are permanently on public display. ${ }^{68}$ The exception covers the unauthorized reproduction and representation of 'architectural works and sculptures, located permanently on public roads'. ${ }^{69}$ Unlike section 62 of CDPA 1988, the use is covered as long as it is 'made by natural persons to the exclusion of commercial uses' ${ }^{70}$

63. InfoSoc Dir. Art 5(3)(h).

64. The European Commission launched a public consultation on 23 March 2016, asking, among other things for public opinion on a mandatory panorama exception for either non-commercial uses or both commercial and non-commercial uses. However, the exception remains non-obligatory. See European Commission, Synopsis Report on the Results of the Public Consultation on the 'Panorama Exception' (14 September 2016), available at <http://ec.europa.eu/information_society/ newsroom/image/document/2016-37/synopsis_report_-_panorama_exception_-_final_17049.pdf> last accessed 23 July 2019.

65. See Pierre-Carl Langlais, 'Public Artworks and the Freedom of Panorama Controversy: A Case of Wikimedia Influence' (2017) 6(1) Internet Policy R. 1.

66. See Ralph E Lerner and Judith Bresler, Art Law: The Guide for Collectors, Investors, Dealers \& Artists (4th edn, Practicing Law Institute, New York 2012) at 1071.

67. See Jonathan Barrett, 'Time to Look Again: Copyright and Freedom of Panorama' (2017) 48 Victoria U. Wellington L. Rev. 261, at 276-7.

68. See The Law for a Digital Republic (Loi por une République Numérique), Article 39, available at $<$ https://www.legifrance.gouv.fr/affichTexte.do;jsessionid=9DEEA6988429DA46913A9B 565C110D2C.tpdila14v_3 ?cidTexte $=$ JORFTEXT000033202746\&categorieLien $=\mathrm{id}>$ last accessed 23 July 2019.

69. Intellectual Property Code (FR), L. 122-5 $11^{\circ}$. For the English translation of the text, see Marie-Andree Weiss, 'The New, But Narrow, French Freedom of Panorama Exception', The 1709 Blog, 18 October 2016, available at <http://the1709blog.blogspot.co.uk/2016/10/the-newbut-narrow-french-freedom-of.html?m=1> last accessed 23 July 2019.

70. Ibid. 
There are two problems with our use of Really Good being covered by the exception. First of all, while Whitehall is a public road, it is unclear if the term covers Trafalgar Square, which is a square, not a road. As one commentator argued, the term might be excluding public places other than public roads, such as public parks or stations. ${ }^{71}$ The rationale behind the exception lies in the distinction between public/private spaces. Therefore, such a restrictive interpretation would be contradictory to Recital 32 of the InfoSoc Directive, since it would unreasonably limit interaction with sculptures that are in public spaces other than public roads. However, a judicial interpretation regarding this aspect remains to be seen.

Secondly, the French regulation is limited to non-commercial uses, but the provision is silent on the concept of commercial use. The Directive is equally silent since Article 5(3)(h) does not limit the scope of the exception to non-commercial uses. Again, it may be argued that limiting the scope of Article 5(3)(h) would contradict Recital $32 .{ }^{72}$ However, if we were to rely on L. $122-511^{\circ}$ of the French Intellectual Property Code, our use would also be subject to the non-commercial use criterion. We may argue that our use is non-commercial since there is no financial gain provided for us from screening our documentary within the festival's programme. It is hard to foresee if the festival's financial gain would challenge our use since the concept of commercial use is unclear in the context of the panorama exception. However, if we decide to distribute the work for financial gain following the festival screening, our use would fall outside the scope of the French provision.

On the other hand, the panorama exception has long been a part of the copyright system in Germany. ${ }^{73}$ The current provision allows users to reproduce, distribute and make available 'the public works located permanently on public roads and ways or public open spaces'. ${ }^{74}$ The German provision is more flexible than the French one in terms of the scope of the public space in which the work is displayed. Since the provision includes the works located in public open spaces, our uses would be covered by the German exception. And unlike the French provision, the exception is neither limited to non-commercial uses, nor to the uses made by natural people in Germany. Therefore, if we were to screen Her Story in Germany, we would rely on section 59 of the German Copyright Act for our unauthorized uses of Really Good and the Monument. However, German case law is the only one among the three countries whose law this article has so far examined that involves a judgment on a work's status of permanence. Therefore, a closer look at the case of the so-called Wrapped Reichstag may provide guidance to facilitate the exception in Germany for our use of Really Good.

On 24 June 1995, the historic Reichstag building in Berlin was wrapped with white fabric, to be kept on for 14 days, as a project of artist duo Christo Vladimirov Javacheff (Christo) and Jeanne-Claude Marie Denat (Jeanne-Claude). ${ }^{75}$ Following the end of the

71. See Eleonora Rosati, 'Freedom of Panorama in France: Could Even a Visit to Pere Lachaise Become a Problem?', The IPKat, 29 April 2016, available at <http://ipkitten.blogspot.co.uk/2016/ 04/freedom-of-panorama-in-france-could.html > last accessed 23 July 2019.

72. For an analysis of the issue of flexibility for the Member States in their implementations of Article 5 exceptions, see Eleonora Rosati, 'Copyright in the EU: In Search of (In)Flexibilities' (2014) 9(7) J. of I.P. L. \& Practice 585, at 592-6.

73. See Elizabeth Adeney, 'Authors' Rights in Works of Public Sculpture: A German/ Australian Comparison' (2002) 33(2) Int'l R. of I.P. and Competition L. 164, at 169 (stating that the exception was included in 1876 federal legislations, and some earlier local statutes).

74. German Copyright Act, s 59 (WIPO Translation).

75. See Christo and Jeanne-Claude, 'Wrapped Reichstag', available at $<$ http://christojeanne claude.net/projects/wrapped-reichstag?view=info> last accessed 23 July 2019. 
exhibition, the materials were recycled. ${ }^{76}$ When a third party photographed the wrapped building and made postcards out of it, the artist duo took action, and the controversy between the parties was eventually resolved by the Bundesgerichtshof (German Federal Court of Justice, BGH). ${ }^{77}$ The defendant relied on section 59 of the German Copyright Act. ${ }^{78}$ and the central issue was the requirement of permanence for the use to be covered by the exception. According to the BGH's interpretation, a work is permanently on public display if it is installed for the work's whole life. ${ }^{79}$ If a work is removed from public display 'in advance to a period that is shorter than the natural life of the work', its display, the court stated, is of a temporary nature. ${ }^{80}$ The defendant argued that since the work was destroyed following the exhibition, it was publicly displayed for the whole length of its life, thus it was permanently on public display. ${ }^{81}$ However, the destruction of the work was deemed irrelevant by the BGH, since the conclusive factor was stated to be the choice of the artist duo. ${ }^{82}$

In the case of Really Good, the lifespan of the sculpture is surely longer than the planned duration of public display. However, the temporariness of the public display is not the choice of the sculptor, but rather he acknowledges it prior to the placement of the sculpture. It is a borderline issue to decide whether Mr Shrigley's approval of the conditions regarding the duration of public display would be an artistic choice. But the significant difference between Really Good and Wrapped Reichstag is the duration of their display. The Wrapped Reichstag installation was present in Berlin's landscape for two weeks, making it a special event, something outside the natural flow of everyday life in Berlin. Really Good on the other hand, had been a part of London's daily life for one and a half years, from September 2016 to March 2018. ${ }^{83}$ The considerably longer display period of Really Good and the continuity of the Fourth Plinth commissions' display create a difference between the two works. While Wrapped Reichstag was an escape from daily life, Really Good was a part of it. And while the people of Berlin engaged with Wrapped Reichstag for a given period, the people of London expect Fourth Plinth sculptures to be there to interact with on a casual, someday basis. Therefore, I believe we have a strong argument for relying on section 59 of the German Copyright Act for our use of Really Good in a possible future screening in Germany.

\section{FESTIVALS AS PROBLEM SOLVERS}

This article has so far argued that there are three problems for documentary makers in utilizing copyright limitations and exceptions to reduce the burden of the copyright clearance process for their films. The first one is the necessity for legal guidance in utilizing the limitations and exceptions, which is not easy to obtain for some documentary makers. The second one is the fear of liability that leads documentary makers to avoid utilizing limitations and exceptions. And the last one is that the limitations and exceptions are unharmonized at the international level. While the last problem remains

76. Ibid.

77. BGH, 24.01.2002, Case I ZR 102/99. Reported in [2004] E.C.C. 25; [2003] E.C.D.R. 7.

78. Re Postcards of the Wrapped Reichstag, [2004] E.C.C. 25, at 390.

79. Ibid at 393.

80. Ibid at 393-4.

81. Ibid at 395 .

82. Ibid at 393-4.

83. Denham (n 44); Khan (n 52). 
to be resolved at an inter-governmental level, festivals could ease the burden of copyright clearance for documentary makers through helping them to solve the former two problems.

\subsection{What makes festivals suitable problem solvers?}

\subsubsection{Being the primary distribution channel for documentaries}

According to BFI's Statistical Yearbook 2017, there were 1585 independent domestic UK films produced between 2003 and 2014 that were not released theatrically. ${ }^{84}$ Out of those 1585 films, 1240 of them had a budget of less than $£ 500000 .{ }^{85}$ While only 62 of those low-budget films were shown on television, 490 of them met with an audience through festival screenings. ${ }^{86}$ These numbers show the importance of festivals as an alternative distribution channel for low-budget independent films. ${ }^{87}$ The significance of festivals as a distribution channel is even more visible when it comes to documentaries. The 2016 survey of the Center for Media \& Social Impact (CMSI) states that 73 per cent of documentaries that year had been distributed through festivals ${ }^{88}$ whereas the percentage for public television distribution was 39 per cent, and 26 per cent for theatrical distribution. ${ }^{89}$

The difference between distribution channels is noteworthy. While the costliness of theatrical and broadcast distribution may be one of the reasons for low-budget documentaries to lean towards festivals, openness to more diversified content is definitely another. Some festivals with a focus on specific issues like human rights and LGBT and environmental issues are more suitable choices for some documentaries; since mainstream media channels may tend to overlook such issues. ${ }^{90}$ Even though self-distribution via online platforms is also a favoured model, ${ }^{91}$ documentary film festivals are perfect places to interact with a focused community, as they provide an environment in which the audience can be informed 'in a supportive, non-threatening atmosphere, which creates an excellent basis for exchange and dialogue'. ${ }^{92}$

\subsubsection{Investing in the future of the medium}

A number of festivals have undertaken a mission of improving the medium by investing in new documentary filmmakers. Some examples that we consider to apply to

84. BFI, Statistical Yearbook 2017 (BFI 2017) at 101.

85. Ibid at 101.

86. Ibid at 103.

87. Kenneth Turan, Sundance to Sarajevo: Film Festivals and the World They Made (University of California Press, Berkeley 2002) at 8 (defining festivals as 'an alternative distribution network').

88. Caty Borum Chattoo, The State of the Documentary Field: 2016 Survey of Documentary Industry Members (CMSI 2016) at 6.

89. Ibid at 23 .

90. For a comprehensive analysis of festivals focusing on human rights, queer rights, environmental issues and other problems that may be overlooked by the mass media, see Dina Iordanova and Leshu Torchin (eds), Film Festivals and Activism (St Andrews Film Studies, 2012); Carole Roy, “'Why Don't They Show Those on TV?” Documentary Film Festivals, Media and Community' (2012) 31(3) Int'l J. Lifelong Education 293.

91. Chattoo (n 88) at 23 (stating that $38 \%$ of the documentaries tried self-distribution models). 92. See Carole Roy, Documentary Film Festivals: Transformative Learning, Community Building \& Solidarity (Sense Publishers, Rotterdam 2016) at 9. 
Her Story are as follows: DOK Leipzig guides projects in development in its DOK CoPro Market every year. ${ }^{93}$ In its 13 th edition, DOK Co-Pro Market provided guidance for 35 projects, ${ }^{94}$ and further financial support is provided for 'the best female-driven documentary film project at the DOK Co-Pro Market', in collaboration with the European Women's Audiovisual Network (EWA). ${ }^{95}$ The Points North Institute (PNI), organizer of the Camden International Film Festival, has five different artist programmes. ${ }^{96}$ Four of the five programmes specifically focus on the documentary medium. Among them, Shortform Editing Residency provides funding, a chance to meet further funders and distributors, and accommodation for independent non-fiction filmmakers and multimedia journalists who work on short or episodic documentaries. ${ }^{97}$ And a North Star Scholarship is available for documentary makers aged between 21 and 29 who have not completed their first feature-length documentary. ${ }^{98}$ Similarly, the International Documentary Film Festival Amsterdam (IDFA) invests in new talent through its IDFAcademy ${ }^{99}$ and provides further help for documentary projects in developing countries with the IDFA Bertha Fund. ${ }^{100}$

\subsection{What could festivals do?}

Copyright clearance is primarily a problem of budget. Utilizing limitations and exceptions might indeed reduce some costs. However, as illustrated in the previous chapter, limitations and exceptions might be unpredictable. Considering the fact that not all such projects are driven by six IP-specialist LLM students, a legal consultancy is necessary for a documentary to utilize limitations and exceptions. Furthermore, with more territories in which to distribute the film, more legal consultancy is required. And legal consultancy may itself be very costly. Considering the difficulty of obtaining funding for documentarians at the beginning of their careers, avoiding copyright materials may be the only way for them to carry out their projects. The constant inaccessibility of copyright materials may limit documentary makers' horizons by forcing them to constantly overlook copyright materials, which constitute a large part of our contemporary culture. If festivals step in and help new documentary makers to utilize copyright protected materials more freely, however, the medium may flourish as a result of copyright materials being more accessible. I believe that documentary film festivals could be a part of the solution to the problem of copyright clearance in two ways.

93. DOK Leipzig, 'DOK Co-Pro Market', available at <https://www.dok-leipzig.de/en/industry/ co-pro-market/about> last accessed 23 July 2019.

94. Ibid.

95. EWA, 'EWA Development Award at DOK Co-Pro Market Leipzig', available at <http:// www.ewawomen.com/en/news/ewa-development-award-at-dok-co-pro-market-leipzig.html> last accessed 23 July 2019.

96. PNI, 'Artist Programs', available at <https://pointsnorthinstitute.org/artist-programs/> last accessed 23 July 2019.

97. PNI, 'Shortform Editing Residency', available at <https://pointsnorthinstitute.org/artistprograms/shortform-residency/> last accessed 23 July 2019.

98. PNI, 'North Star Scholarship', available at <https://pointsnorthinstitute.org/artist-programs/ north-star-residency/> last accessed 23 July 2019.

99. IDFA, 'IDFAcademy', available at $<$ https://www.idfa.nl/en/info/idfacademy $>$ last accessed 23 July 2019.

100. IDFA, 'IDFA Bertha Fund', available at <https://www.idfa.nl/en/info/idfa-bertha-fund> last accessed 23 July 2019. 
The first way is by adopting a more inclusive approach towards utilizing limitations and exceptions. As stated above, a great number of festivals require the submissions to obtain 'all necessary rights and permissions for third-party materials included in their films'. ${ }^{101}$ Festivals could encourage the applicants to use limitations and exceptions when it is appropriate. While it would not be as risk-free as their current submission policies, changing the norm against using limitations and exceptions is a necessity. To minimize the risk, highlighting the unauthorized uses and stating the relied on limitations or exceptions could be one of the requirements for submission.

Another way of minimizing the risk is providing the necessary tools to the documentary makers for them to utilize limitations and exceptions. This is, I suggest, the second way that festivals could be helpful in solving the copyright clearance problem. Considering that festivals operate within one legal jurisdiction, a festival may provide information regarding its respective jurisdiction's limitations and exceptions regime. With more festivals providing information regarding their jurisdiction, it would be easier for documentary makers to utilize limitations and exceptions in different jurisdictions. The information could be provided in a number of ways. As examined above, some documentary festivals organize panels such as Points North Forum, ${ }^{102}$ or educational programmes like IDFAcademy, ${ }^{103}$ where the business, craft and future of the medium is discussed. Including copyright experts on such panels and educational programmes would be an appropriate way of providing relevant information.

Providing online guidance is another way that festivals could make it easier to use limitations and exceptions. Some organizations that work in the creative fields provide copyright-related guidelines for their members produced specifically for their respective media. ${ }^{104}$ Considering festival's websites' high degree of accessibility, they would be well placed to direct documentary makers seeking related information to trustworthy sources, the value of which has been increasing with the rise of misinformation in the digital age. Such efforts would provide access to information for documentary makers who seek it. It would also lead documentary makers who generally avoid copyright-protected material to further look into limitations and exceptions.

A more direct approach would be to include a limitations and exceptions consultancy service in artist programmes. Guidance by a legal expert on national limitations and exceptions may be provided for a limited number of projects after a process of selection upon submission. The structure of DOK Co-Pro Market or PNI's Shortform Editing Residency may be taken as an example. Hence, guidance could be provided for a project with actual problems. Such guidance may be beneficial for both the projects that have already relied on an exception in their territory of origin and want to be safe for the same use in another territory, and for documentary makers working on their first film. To illustrate, a filmmaker who relies on fair use in the US may seek advice to see if she could rely on one of the fair dealing exceptions in the UK. This model would be helpful for fewer projects compared to the first model, but it would be more effective, given that it would provide solutions for specific uses.

101. Austin Film Festival (n 19).

102. PNI, 'Points North Forum', available at <https://pointsnorthinstitute.org/artist-programs/ points-north-forum/> last accessed 23 July 2019.

103. IDFA (n 99).

104. See eg Association of Illustrators, 'Resources', available at <https://theaoi.com/resources/> last accessed 23 July 2019; Artists' Union England, 'Copyright Guide for Visual Artists', available at <https://www.artistsunionengland.org.uk/copyright-advice-now-available-for-aue-members/> last accessed 23 July 2019. 
It is true that the solutions I suggest do not ease the problem of unharmonized limitations and exceptions, which remains to be solved on an inter-governmental level. Rather, what festivals could achieve through adapting the suggestions made above is to spread the utilization of limitations and exceptions and prevent them from being marginalized within the day-to-day operations of the film industry. The more projects utilize limitations and exceptions, the more their use would spread within the industry, and hence the easier it would be for future documentary makers to use copyright-protected materials. ${ }^{105}$

\section{CONCLUSION}

What copyright protects constitutes the shared cultural values and intellectual efforts of humankind. The need to feature copyright-protected materials in documentaries to reflect reality as it is will certainly continue. As this article argued, however, the current copyright regime limits documentary makers in their engagements with contemporary culture as it fails to keep the balance it was designed to provide. While the current regime was intended to safeguard a balance between rightsholders and third party authors via the limitations and exceptions provisions, this balance is not necessarily achieved within the current regime. This is because the limitations and exceptions are inaccessible due to the unharmonized international copyright system, the costliness of obtaining proper legal consultancy, and the high risks associated with utilizing them. As a result, the utilization of limitations and exceptions has become rare, which, in turn, makes them insufficient to take on the role they were originally designed for.

Festivals could guide the documentary community to utilize limitations and exceptions. Such guidance would reduce the fear of liability and enable more documentary makers to utilize limitations and exceptions. Once using limitations and exceptions becomes more widespread, the community would start to develop know-how on how to utilize them, which would in return be beneficial for future documentarians. Hence, festivals may help documentary projects to reduce their budgets, to use copyright materials as their externalized evidence, and to discuss contemporary culture more directly via utilizing copyright materials.

\section{BIBLIOGRAPHY}

\section{Primary sources}

Berne Convention for the Protection of Literary and Artistic Works.

BGH, 24.01.2002, Case I ZR 102/99. Reported in [2004] E.C.C. 25; [2003] E.C.D.R. 7.

City of Westminster, Planning Applications Sub-Committee Report on Trafalgar Square, London, WC2 (16 February 2012), at 232, available at <http://committees.westminster.gov.uk/ Data/Planning\%20Applications\%20Committee/20120216/Agenda/ITEM\%2007-Trafalgar\% 20Square,\%20WC2.PDF> last accessed 18 March 2018.

Copyright Act 1911 (UK).

Copyright, Designs and Patents Act 1988.

105. Africa (n 23). 
Directive 2001/29/EC of the European Parliament and of the Council of 22 May 2001 on the harmonization of certain aspects of copyright and related rights in the information society [2001] OJ L167/10.

Fairness in Music Licensing, Panel Report, June 15, 2000, WT/DS/160/R.

German Copyright Act of 9 September 1965 (2016).

Intellectual Property Code (FR).

Judgment of 3 September 2014, Johan Deckmyn and Another $v$ Helena Vandersteen and Others, Case C-201/13, EU:C:2014:2132.

Khan S, Mayor of London, MD2179 Fourth Plinth Programme 2017-2021 (26 October 2017), available at $<$ https://www.london.gov.uk/sites/default/files/md2179_fourth_plinth_cib_final_ version_signed_pdf.pdf> last accessed 18 March 2018.

The Law for a Digital Republic (Loi por une République Numérique) (FR).

Trade-Related Aspects of Intellectual Property Rights.

Viscount Haldane, Imperial Copyright, Hansard, HL, Vol. 10, cols 113-66.

WIPO Copyright Treaty.

\section{Secondary sources}

Adeney E, 'Authors' Rights in Works of Public Sculpture: A German/Australian Comparison' (2002) 33(2) Int'l R. of I.P. and Competition L. 164.

Africa M, 'The Misuse of Licensing Evidence in Fair Use Analysis: New Technologies, New Markets, and the Courts' (2000) 88(4) Cal. L.J. 1145.

Aoki K, 'Adrift in the Intertext: Authorship and Audience Recording Rights - Comment on Robert H. Rotstein, Beyond Metaphor: Copyright Infringement and the Fiction of the Work' (1993) 68 Chi.-Kent L. Rev. 805.

Aoki K, Boyle J and Jenkins J, Bound by Law? Tales from the Public Domain. New Expanded Edition (Duke University Press, Durham, NC 2008).

Arendt H, The Human Condition (2nd edn, The University of Chicago Press, Chicago, IL 1958).

Artists' Union England, 'Copyright Guide for Visual Artists', available at <https://www.artist sunionengland.org.uk/copyright-advice-now-available-for-aue-members/> last accessed 22 July 2019.

Association of Illustrators, 'Resources', available at <https://theaoi.com/resources/> last accessed 22 July 2019.

Association of Independent Video and Filmmakers and others, Documentary Filmmakers' Statement of Best Practices in Fair Use (AUSOC 2005).

Aufderheide P and Jaszi P, 'Untold Stories: Creative Consequences of the Rights Clearance Culture for Documentary Filmmakers', Center for Social Media, 2004.

Aufderheide P and Sinnreich A, 'Documentarians, Fair Use, and Free Expression: Changes in Copyright Attitudes and Actions with Access to Best Practices' (2016) 19(2) Information, Community \& Society 178.

Austin Film Festival, '2018 Austin Film Festival Film Competition Rules', available at <https:// austinfilmfestival.com/submit/film/rules/> last accessed 14 March 2018.

Barthes R, Image, Music, Text, Stephen Heath trans (Fontana Press, London 1977).

Barrett J, 'Time to Look Again: Copyright and Freedom of Panorama' (2017) 48 Victoria U. Wellington L. Rev. 261.

Bendjelloul M, Searching for Sugar Man (2012).

Bently L and Sherman B, Intellectual Property Law (4th edn, Oxford University Press, Oxford 2014).

BFI, Statistical Yearbook 2017 (BFI 2017).

Burrell R and Coleman A, Copyright Exceptions: The Digital Impact (Cambridge University Press, Cambridge 2005).

Chattoo CB, The State of the Documentary Field: 2016 Survey of Documentary Industry Members (CMSI 2016).

Cherry D, 'Statues in the Square: Hauntings at the Heart of Empire' (2006) 29(4) Art History 660 . 
Christo and Jeanne-Claude, 'Wrapped Reichstag', available at <http://christojeanneclaude.net/ projects/wrapped-reichstag?view=info > last accessed 21 March 2018.

CopyrightUser.Org, 'Exceptions', available at <http://www.copyrightuser.org/understand/ exceptions/> last accessed 26 March 2018.

D'Agostino G, 'Healing Fair Dealing? A Comparative Analysis of Canada's Fair Dealing to U.K. Fair Dealing and U.S. Fair Use' (2008) 53 McGill L.J. 309.

Denham J, 'Fourth Plinth: David Shrigley's Giant Thumbs Up "Really Good" Unveiled in London's Trafalgar Square', Independent, 29 September 2016, available at $<\mathrm{https}$ ://www. independent.co.uk/arts-entertainment/art/news/fourth-plinth-david-shrigley-trafalgar-squaresadiq-khan-really-good-thumbs-up-london-brexit-a7337026.html> last accessed 19 March 2018.

Documentary Organization of Canada (DOC), Copyright and Fair Dealing: Guidelines for Documentary Filmmakers (DOC 2010).

DOK Leipzig, 'DOK Co-Pro Market', available at <https://www.dok-leipzig.de/en/industry/copro-market/about> last accessed 26 March 2018.

Donaldson MC, 'Refuge from the Storm: A Fair Use Safe Harbor for Non-Fiction Works' (2012) 59 J. Copyright Soc'y USA 477.

Eitzen D, 'When is a Documentary? Documentary as a Mode of Reception' (1995) 35(1) Cinema Journal 81.

European Commission, Synopsis Report on the Results of the Public Consultation on the 'Panorama Exception' (14 September 2016), available at <http://ec.europa.eu/information society/newsroom/image/document/2016-37/synopsis_report_-_panorama_exception_-_ final_17049.pdf> last accessed 18 March 2018.

EWA, 'EWA Development Award at DOK Co-Pro Market Leipzig', available at <http://www. ewawomen.com/en/news/ewa-development-award-at-dok-co-pro-market-leipzig.html> last accessed 26 March 2018.

Franklin B and McLeod K, Copyright Criminals (2009).

Geiger C et al., 'Limitations and Exceptions as Key Elements of the Legal Framework for Copyright in the European Union - Opinion of the European Copyright Society on the Judgment of the CJEU in Case C-201/13 Deckmyn (2015) 46(1) Int. Rev. of I.P. and Comp. L. 93.

Gervais DJ, 'Making Copyright Whole: A Principled Approach to Copyright Exceptions and Limitations' (2008) 5 U. Ottawa L. \& Tech. J. 1.

Ginsburg JC, 'Toward Supranational Copyright Law? The WTO Panel Decision and the “Three-Step Test" for Copyright Exceptions' (2001) (2001) 187 R.I.D.A. 2.

Gormley A, 'One \& Other, Fourth Plinth Commission, Trafalgar Square, London, England, 2009', available at <http://www.antonygormley.com/show/item-view/id/2277> last accessed 23 March 2018.

Griffiths J, 'Rhetoric \& the "Three-Step Test": Copyright Reform in the United Kingdom' (2010) 32(7) E.I.P.R. 309.

Hugenholtz PB and Okediji RL, Conceiving an International Instrument on Limitations and Exceptions to Copyright: Final Report (IViR, UMLS March 6, 2008).

Hugenholtz PB and Senftleben MRF, Fair Use in Europe: In Search of Flexibilities (IViR, 2011).

IDFA, 'IDFAcademy', available at $<$ https://www.idfa.nl/en/info/idfacademy $>$ last accessed 26 March 2018.

IDFA, 'IDFA Bertha Fund', available at <https://www.idfa.nl/en/info/idfa-bertha-fund > last accessed 26 March 2018.

Imperial War Museum, 'Memorial: Women of World War Two', available at <https://www. iwm.org.uk/memorials/item/memorial/51288> last accessed 21 March 2018.

Iordanova D and Torchin L (eds), Film Festivals and Activism (St Andrews Film Studies, 2012).

Jones J, 'Thumbs Up to David Shrigley's Fabulously Feel-Bad Fourth Plinth', The Guardian, 29 September 2016, available at <https://www.theguardian.com/artanddesign/2016/sep/29/ david-shrigley-really-good-fourth-plinth-trafalgar-square> last accessed 18 March 2018.

Langlais P, 'Public Artworks and the Freedom of Panorama Controversy: A Case of Wikimedia Influence' (2017) 6(1) Internet Policy R. 1. 
Lerner RE and Bresler J, Art Law: The Guide for Collectors, Investors, Dealers \& Artists (4th edn, Practicing Law Institute, New York 2012).

Liu D, 'English Copyright Law Makes the Poor “Snowman” Sculpture Poorer' (2013) 35(11) European I.P. L. 674.

Liu D, 'Of Sculpture' (2014) 36(4) E.I.P.R. 229.

Maloof J and Siskel C, Finding Vivian Maier (2013).

McLean G, 'My Life, The Horror Movie', The Guardian, 16 April 2005, available at <https:// www.theguardian.com/film/2005/apr/16/features.weekend> last accessed 14 March 2018.

Netanel NW, Copyright's Paradox (Oxford University Press, Oxford 2008).

Nichols B, Introduction to Documentary (Indiana University Press, Bloomington, IN 2010).

Nichols B, 'The Question of Evidence, the Power of Rhetoric and Documentary Film', in Brian Winston (ed), The Documentary Film Book (BFI, London 2013).

Özkırımlı U, Contemporary Debates on Nationalism: A Critical Engagement (Palgrave Macmillan, Basingstoke 2005).

PNI, 'Artist Programs', available at <https://pointsnorthinstitute.org/artist-programs/> last accessed 26 March 2018.

PNI, 'North Star Scholarship', available at <https://pointsnorthinstitute.org/artist-programs/ north-star-scholarship/> last accessed 26 March 2018.

PNI, 'Points North Forum', available at <https://pointsnorthinstitute.org/artist-programs/pointsnorth-forum/> last accessed 26 March 2018.

PNI, 'Shortform Editing Residency', available at $<$ https://pointsnorthinstitute.org/shortformresidency/> last accessed 26 March 2018.

Ramsey N, 'The Hidden Cost of Documentaries', The New York Times, 16 October 2005, available at <http://www.nytimes.com/2005/10/16/movies/the-hidden-cost-of-documentaries. html $>$ last accessed 16 March 2018.

Ricketson S and Ginsburg JC, International Copyright and Neighbouring Rights: The Berne Convention and Beyond (2nd edn, Oxford University Press, Oxford 2006).

Rosati E, 'Copyright in the EU: In Search of (In)Flexibilities' (2014) 9(7) J. of I.P. L. \& Practice 585.

Rosati E, 'Freedom of Panorama in France: Could Even a Visit to Pere Lachaise Become a Problem?', The IPKat, 29 April 2016, available at <http://ipkitten.blogspot.co.uk/2016/04/ freedom-of-panorama-in-france-could.html > last accessed 20 March 2018.

Roy C, Documentary Film Festivals: Transformative Learning, Community Building \& Solidarity (Sense Publishers, Rotterdam 2016).

Roy C, "'Why Don't They Show Those on TV?" Documentary Film Festivals, Media and Community' (2012) 31(3) Int'l J. Lifelong Education 293.

Sherman B and Bently L, The Making of Modern Intellectual Property Law: The British Experience (Cambridge University Press, Cambridge 1999).

Sontag S, Regarding the Pain of Others (Penguin, London 2004).

Sumartojo S, 'Britishness in Trafalgar Square: Urban Place and the Construction of National Identity' (2009) 9(3) Studies in Ethnicity and Nationalism 410.

Sumartojo S, 'The Fourth Plinth: Creating and Contesting National Identity in Trafalgar Square, 2005-2010' (2012) 20(1) Cultural Geographies 67.

Turan K, Sundance to Sarajevo: Film Festivals and the World They Made (University of California Press, Berkeley 2002).

Weiss M, 'The New, But Narrow, French Freedom of Panorama Exception', The 1709 Blog, 18 October 2016, available at <http://the1709blog.blogspot.co.uk/2016/10/the-new-butnarrow-french-freedom-of.html?m=1> last accessed 20 March 2018.

Wong W, 'Errors \& Omissions \& Rights, Oh My! A Guide to Protecting Your Film', IDA Documentary Magazine, 6 April 2012, available at <https://www.documentary.org/magazine/ errors-omissions-rights-oh-my-guide-protecting-your-film> last accessed 23 July 2019. 